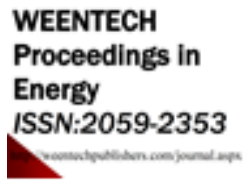

Available online at www.weentechpublishers.com

$2^{\text {nd }}$ Global Conference on Energy and Sustainable Development, GCESD2018, 18-20 December 2018, John McIntyre Conference Centre, The University of Edinburgh, United Kingdom

\title{
Determining the UK's Potential for Heat Recovery from Wastewater using Steady State and Dynamic Modelling - Preliminary Results
}

\author{
S. Farman Ali*, A. Gillich \\ School of the Built Environment and Architecture, London South Bank University \\ "Corresponding author's mail: alis133@lsbu.as.uk \\ 103 Borough Road, London SE1 0AA, United Kingdom
}

\begin{abstract}
By 2050, UK plans to create 'low carbon society'. To meet this ambitious target, UK's heating sector must be completely decarbonized. The identification and deployment of low carbon heating sources is thus an urgent policy and research priority. Recovering heat from sewage wastewater is relatively new and attractive option as it can help UK move towards its climate change targets while decarbonising the heating sector \& reducing the reliance on fossil fuels. In the domestic context, wastewater is normally discharged at higher temperature than ambient (a carrier of heat/ thermal energy) losses its energy to (ground) environment before it reaches to WWTP. Recovering this heat from wastewater could be a considerable source of energy, revenue and is environmental friendly as it results in the reduction of GHG emissions, resource conservation and in increase share of renewable energy. In last decade, many cities around the world have successfully implemented wastewater thermal energy recovery but UK is lagging behind. Pilot project such as in Scotland is leading the way, but further research is needed to build the evidence base and replicate the concept elsewhere in UK. The Home Energy 4 Tomorrow (HE4T) project at London South Bank University (LSBU) was created to address this evidence gap. The project objectives include sizing the heat potential recoverable from wastewater at designated sites. The current paper forms part of the HE4T project and the second in series of output on wastewater heat recovery in UK. In this paper we present some initially measured data, variations in wastewater temperature and flow, steady state and dynamic model results wastewater temperature and the potential heat recovery of the designated site. Early results, their limitations and possible routes to address these limitations are discussed along with policy implications for UK heat strategy.
\end{abstract}

Keywords: Energy recovery; Heat recovery; Urban wastewater; Sewer; Wastewater temperature, Wastewater flow; Combined sewer; Wastewater treatment plant; Heat pump; Heating of buildings; Modelling; Simulation; TEMPEST

Copyright (C) 2019 Published by WEENTECH Ltd. The peer-review process is under responsibility of the scientific committee of the $2^{\text {nd }}$ Global Conference on Energy and Sustainable Development, GCESD2018

\section{Abbreviations}

$\begin{array}{ll}\text { COD } & \text { Chemical Oxygen Demand } \\ \text { GHG } & \text { Greenhouse Gases } \\ \text { TWh } & \text { Tera Watt hour } \\ \text { WWTP } & \text { Wastewater Treatment Plant }\end{array}$

Copyright ( $) 2019$ Published by WEENTECH Ltd. The peer-review process is under responsibility of the scientific committee of the 2nd Global Conference on Energy and Sustainable Development, GCESD2018

https://doi.org/10.32438/WPE.58181 


\section{Introduction}

In order to meet the legally binding carbon reduction targets, the UK heating sector must be completely decarbonized by 2050 . Utilising secondary heat sources like wastewater heat recovery can play an important role in meeting these targets [1]. Recovering waste heat from urban wastewater (often referred as sewer water or sewage) is an attractive option as thermal energy that can be recovered, Page $\mid 108$ offsetting fossil-fuel use and reducing GHG emissions. Wastewater or sewage when discharged from point of use is at higher temperature than ambient (roughly contains $80 \%$ thermal and $19.9 \%$ chemical and rest other form of energy embedded in it). It is possible to capture and reuse this thermal energy that would otherwise be lost to the environment before it reaches the Wastewater Treatment Plant (WWTP). The thermal energy available in waste water is described as 'low grade' heat and can be used for heating and cooling purposes. However, wastewater as an energy source has so far been under-utilised due to a range of technical barriers including: the uncertain impacts of lowering sewage temperatures on the sewer network; risks of increased blockages, reduced sewer capacity, risk of damage to sewer pipes, and impacts to WWTP efficiency. Waste water heat recovery also faces practical challenges such the need for heat pumps (currently also lagging in the UK), the comparatively low cost of natural gas, longer payback period of heat recovery systems, and in some cases finding a suitable application for the low grade heat.

In past the two decades, wastewater heat recovery technology deployment has grown. Many cities around the world have successfully implemented wastewater thermal energy recovery but the UK is lagging behind [2]. Projects such as Borders College, Galashiels, Scotland [3] are leading the way, but further experimental research is needed to build the evidence base and replicate and de-risk the concept elsewhere in the UK.

The Home Energy 4 Tomorrow (HE4T) project at London South Bank University (LSBU) was created to address this evidence gap along with a clean-tech firm (ICAX Ltd.), as well as two utility partners (Thames and Anglian Water).

In this paper we set the overall context for wastewater heat recovery systems in the UK, describe the HE4T project case study, then present some initially measured data, variations in wastewater temperature and flow, steady state and dynamic modelling to determine the energy potential of wastewater. Early results, their limitations and possible routes to address these limitations are discussed along with policy implications for UK heat strategy.

\section{Overview}

\subsection{Wastewater Heat Recovery}

A waste heat recovery system consists of a heat exchanger and a heat pump installed in and/or near the sewer (Fig. 1). The heat exchanger transfers heat from the sewer to the heat pump, which operates as a closed loop system, and absorbs heat from the heat exchanger. A heat pump then upgrades the low grade waste heat to a higher grade temperature that can be delivered to a heating system or a network [4]. The sewage (dirt) does not comes in contact with the working fluid (clean water or refrigerant) in the heat pump system and the recovered energy is reused for heating and cooling purposes. Thus the heat pump works more economically than fossil fuels and efficiently under low temperature conditions (of wastewater) and offers flexibility of integrating within existing or new systems. The recovered energy is ideal for use in district energy systems, serving range of domestic and non-domestic heating loads. Copyright (C 2019 Published by WEENTECH Ltd. The peer-review process is under responsibility of the scientific committee of the 2nd Global Conference on Energy and Sustainable Development, GCESD2018 https://doi.org/10.32438/WPE.58181 
Moreover, the recovered energy is environmentally friendly as it results in the reduction of greenhouse gas emissions, resource conservation and in increase share of renewable energy while protecting the environment from polluting and unsustainable practices.

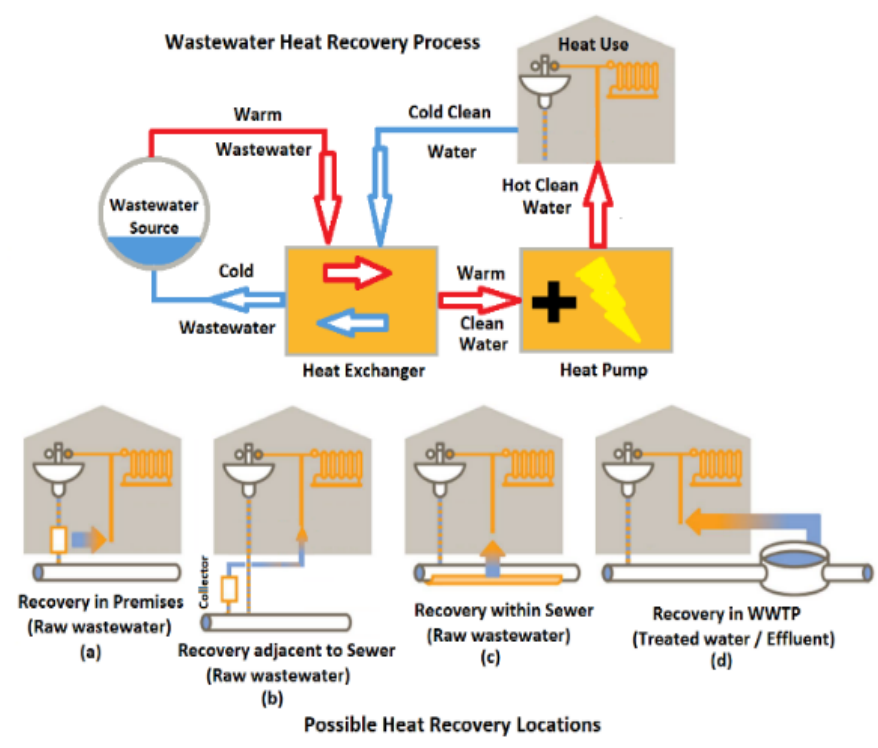

Page | 109

Fig. 1 Wastewater heat recovery process and possible locations of heat recovery $[5,6]$

Wastewater or sewage normally when discharged from point of use is at higher temperature $\left(\sim 30^{\circ} \mathrm{C}\right)$ than ambient and could be reuse that would otherwise be lost to environment before it reaches to WWTP (normally between 12 to $10^{\circ} \mathrm{C}$ ). However, the treatment processes done on wastewater within WWTP can again raise its temperature slightly from that of its entrance value. Therefore, heat recovery can be conducted from both; before WWTP from the influent or after WWTP from the effluent. Each of these options have their own advantages and disadvantages and the final choice depends on the local specific conditions.

Upstream of the WWTP, heat recovery can be done close to the heat source i.e. within the premises of the household / building referred as in-house (Fig 1a). Close to the heat source the sewage temperature is higher with no mixing with other drain water. Producers are also consumers of heat so more extraction is possible close to the home but flow is relatively low and varies in time. The wastewater flow from the nearby sewer can be diverted to a custom made collector or well containing screens to maintain clear intakes to specifically designed shell and tube heat exchanger adjacent to the source (or side-stream) (Fig 1b). In Adjacent to heat source while sewage temperature is high and wastewater is cleaner, its installation requires considerable space. Additionally, the system requires sieves to prevent particle accumulation in the well apart from periodic backwash of the sieve to prevent total or partial clogging. The system can be installed in existing and new developments. In-sewer/ trunk lines arrangements, the heat exchanger itself is directly installed in the base of sewer pipe. These heat exchangers are in form of plates, panels or are pipes with built-in internal or external tube banks (Fig 1c). Because in this arrangement sufficient flow and pressure is available, they have the advantage of experiencing stable

Copyright (C 2019 Published by WEENTECH Ltd. The peer-review process is under responsibility of the scientific committee of the 2nd Global Conference on Energy and Sustainable Development, GCESD2018 https://doi.org/10.32438/WPE.58181 
flowrates but are at low sewage temperatures (due to heat lost to the environment during its flow path in the sewer network). Further, installation of the heat exchanger may not be possible in all cases, for example due to the available length of straight runs or too great a slope [7, 8]. In many cases, these large sewers are combined sewers and weather and natural events like snow melt, rainfall, flood, ground water leakage could alter the sewage temperature significantly. Moreover, fouling and biofilm growth on heat exchanger surfaces of varying degree within sewer requires continuous monitoring, periodic maintenance and permissible oversizing. For all raw wastewater heat recovery arrangements, the common issues are; limited temperature drop due to impact on WWTP performance, fouling and biofilms growth of heat exchanger surfaces, solid handling, effects of seasonal diurnal variations and constant periodic maintenance [7].

Last possible option of heat recovery is either at pumping station wet wells or after WWTP from the discharge from treated water / effluent. For earlier case the wastewater is of similar characteristic as of insewer while for later a much cleaner and stable flow is encountered (Fig 1d). Heat recovery from the WWTP effluent has an advantage of being at slightly higher temperature than influent with a larger, steady and cleaner flow. Since recovery takes place downstream of WWTP no impact on its performance and effluent can be cooled down much more than upstream allowing higher energy potential. However, this option cannot be used in many locations as WWTPs are located remotely where no heat consumers are available and recovered energy can only be used by WWTP itself [7]. Some examples of wastewater heat recovery plants successfully operating around the world are given in appendix.

Some typical technical viability conditions for sewer heat recovery outlined by previous works are; the potential heat recovery site should be a densely populated area corresponding 15 to $30 \mathrm{l} / \mathrm{s}$ of wastewater to the minimum dry weather flow $[7,8,9]$, minimum sewer pipe diameter for existing network should be $800 \mathrm{~mm}[7,9]$, potential heat reclamation site should be in the close proximity to heat consumers approx. 100 to $300 \mathrm{~m}$ (maximum $500 \mathrm{~m}$ ) [7,8,9] and minimum heating load/ requirement should be $\geq 50-200 \mathrm{~kW}$ $[7,8]$. Lastly, the most important requirement is to ensure that that wastewater treatment activities at WWTP are not compromised by sewer heat recovery upstream, thus restricting the sewage temperature at WWTP inlet not to be less than $10^{\circ} \mathrm{C}$. This limit is imposed to minimize any adverse effects on biochemical processes that can influence exiting effluent from the WWTP [7].

\subsection{Modelling of sewer network}

Most widely used techniques to model sewer temperature is linear method or mixture method [9]. The method assumes that the temperature of the mixed sewage downstream must lie somewhere between the temperatures of the main and lateral inflow. However, this method does not take into account the actual heat transfer processes occurring; within the sewer pipe, to/from soil surrounding the pipe or to/from the sewer air within the sewer pipe, thus can only be used as first approximation.

This work uses TEMPEST (TEMPerature ESTimation) - a visually interactive simulation software for design and analysis of sewers. The software is based on pseudo two-dimensional mathematical model of a sewerline and is developed by Eawag - Swiss Federal Institute. TEMPEST determines the sewer response i.e. the axial and spatial distribution of the wastewater temperature in the sewer line - the most important parameter for determining heat recovery and its effects on WWTP. The software can be used for simple steady state calculations in a simple sewer line to full-scale dynamic sewer network with lateral inflows [10]. The numerical model in the software uses mass, heat and momentum balance equations for

Copyright ( $) 2019$ Published by WEENTECH Ltd. The peer-review process is under responsibility of the scientific committee of the 2nd Global Conference on Energy and Sustainable Development, GCESD2018 https://doi.org/10.32438/WPE.58181 
as well as consider heat transfer processes between wastewater, sewer air, pipe, soil and biochemical reactions within the nutrient rich wastewater in the sewer system. As with other simulation softwares, TEMPEST too require inputs; wastewater flow at upstream, wastewater temperature, ambient air pressure, ambient air temperature, ambient relative humidity, pipe material, nominal diameter, wall thickness, pipe slope, COD degradation rate, soil material, penetration depth and soil temperature. The main inputs; wastewater discharge and wastewater temperature can either be inserted as constant values in time or as a Page $\mid 111$ time series. TEMPEST also has a built-in library for pipe and soil properties that can be extended with user defined values [11]. A sewer line consists of two simple elements 'node' followed by 'conduit'. A node represents discontinuity points at the start and end of conduits, e.g. headspace, inflow, lateral inflow, change in pipes diameter, change in pipe and soil properties etc. and is modelled by continuity conditions. Whereas the conduit is mass balance equations in which wastewater flow, air flow and wastewater/vapour temperature are continuous functions in time and space and is modelled by one-dimensional balance equations. A set of continuity conditions (nodes) are mathematically inserted into the mass balance equations (between conduits). Note that a simple model can be of single sewer line while large scale model can contain very large number of sewer lines. A complete mathematical review of the TEMPEST can be found in $[10,11]$.

\section{Case study}

\subsection{Theoretical Potential}

With daily discharge of 16 billion liters of sewage in more than 624,200 kilometers of sewer pipes to pass over to 9,000 WWTPs across UK - the potential of heat recovery is significant [12]. Typical, sewage temperature in UK sewers vary from 10 to $25^{\circ} \mathrm{C}$ with a yearly average of $17.5^{\circ} \mathrm{C}$ [13]. Theoretically, if above daily discharge is cooled by 3 degrees for heat recovery, it is possible to recover up to 20 TWh heat energy annually, enough to heat 1.6 million homes. Similarly, considering heat recovery from the effluent of the largest WWTP in UK, with daily average dry weather flow of 1207 million litres [14] and cooling it by 3 degrees, the recoverable heat potential is approximately $1.5 \mathrm{TWh}$ heat energy annually, enough to heat more than 100,000 homes. In practice not all the heat can be recovered because the total amount of heat is a function of initial temperature of the raw wastewater/effluent, raw wastewater/effluent flow rates, minimum temperature requirements for the raw wastewater/effluent and the efficiencies of the heat exchanger and the heat pump. As shown, there is much theoretical potential along with significant opportunity for future energy reclamation and GHGs emission reduction in the longer term but the UK needs to overcome major practical constraints defined in introduction.

\subsection{Experiments, Data and Model setup}

The paper presents preliminary data collection and modelling carried out for the HE4T project. The major reason of using this preliminary data is that it not only contains the spatial and temporal details of wastewater flowrate and temperatures (normally not available) but it also provides a good opportunity to know the data requirements, quality and gaps. Moreover, this data can also be used in verify the existing modelling tools. Measured data includes raw sewage temperatures, discharge level and velocity. Where discharge cannot be directly measured, wastewater level and velocity can be used to calculate and calibrated against the reference values.

The data presented and analysed in the current paper belongs to a particular monitoring site in London and is for a week period between Monday, $19^{\text {th }}$ March to Sunday, $25^{\text {th }}$ March 2018. The weather during the stated period was dry and hence free of the influence of stromwater runoff on the flow and temperature measurements (dry weather flow). The site considered is combined sewer system (sewer collecting the

Copyright (C 2019 Published by WEENTECH Ltd. The peer-review process is under responsibility of the scientific committee of the 2nd Global Conference on Energy and Sustainable Development, GCESD2018 https://doi.org/10.32438/WPE.58181 
domestic sewage, rainwater, surface water etc.), gravity driven lying around $3 \mathrm{~m}$ beneath the ground. The incoming wastewater belongs to two large catchment areas upstream of $\mathrm{A}$ and $\mathrm{B}$, which merge to a common main sewer collector before $\mathrm{C}$, given in Fig 2. The points $\mathrm{A}$ and $\mathrm{B}$ are measuring data points and $\mathrm{C}$ is the point where heat recovery is expected. The weather related data is taken from closest weather centre from which rain and dry weather days are identified.

For TEMPEST modelling, in order to reduce the complexity of large sewer networks upstream, only last $500 \mathrm{~m}$ length with nominal diameter of $1219 \mathrm{~mm}$ and slope of 0.0091 is simulated for heat recovery potential where energy recovery centre is anticipated. The pipe is circular made of reinforced concrete while soil surrounding the buried pipe is taken as London clay with estimated temperature to be $8^{\circ} \mathrm{C}$ [15]. At approximately $220 \mathrm{~m}$ after point $\mathrm{A}$, there is a drain (A') which is assumed to be dry during this time period and can only allow little air exchange due to openings in the manhole cover. The outside average air relative humidity, air ambient pressure, air ambient temperature and exchange coefficient were $80 \%$, $1015 \mathrm{mbar}, 7.7^{\circ} \mathrm{C}$ and $10 \%$ respectively. The measured daily discharge and temperature at point $\mathrm{A}$ is $0.122 \mathrm{~m}^{3} / \mathrm{s}$ and $7.8^{\circ} \mathrm{C}$ while at point $\mathrm{B}$ - a lateral inflow is $0.04 \mathrm{~m}^{3} / \mathrm{s}$ and $11.9^{\circ} \mathrm{C}$. Downstream of the sewer under consideration there is vast sewer network (populated area) and heat recovery by the energy extracted can be reclaimed before entering to WWTP some $25 \mathrm{~km}$ away.

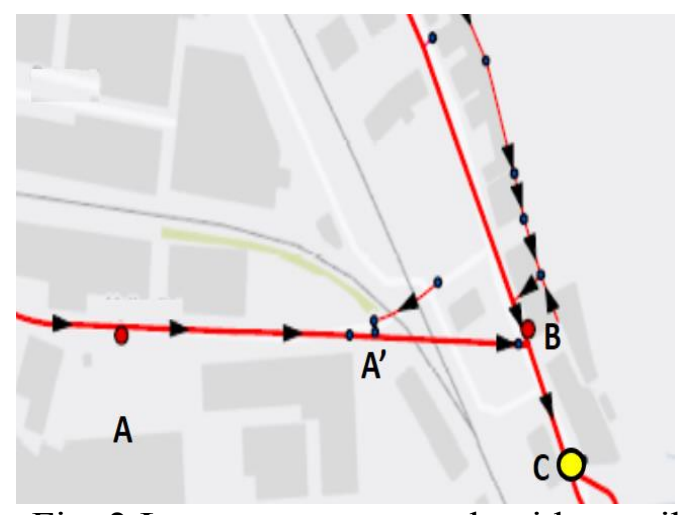

Fig. 2 Large sewer network with possible location of heat recovery at $\mathrm{C}$

\section{Results and Discussions}

\subsection{Data Analysis}

A significant barrier in picking up this technology is lack of data and thus heat recovery modelling. Very few experimental works are accessible in public domain $[9,16,17]$ and those available are confined to measurements of flowrates and temperatures of the single sewer upstream and downstream. Whereas the work presented here considers combined collection sewer with a lateral inflow in the sewer (point B), hence two flowrates and temperatures input profiles have to be considered, however where appropriate this work will compare results to previous works. The measured time series for a week of flowrates and temperatures at point $\mathrm{A}$ and $\mathrm{B}$ are given in Fig 3. Note that no smoothing has been performed on the data. The top schematic (a) shows the flowrates at the measuring points A and B with lower (b) representing the temperatures. 


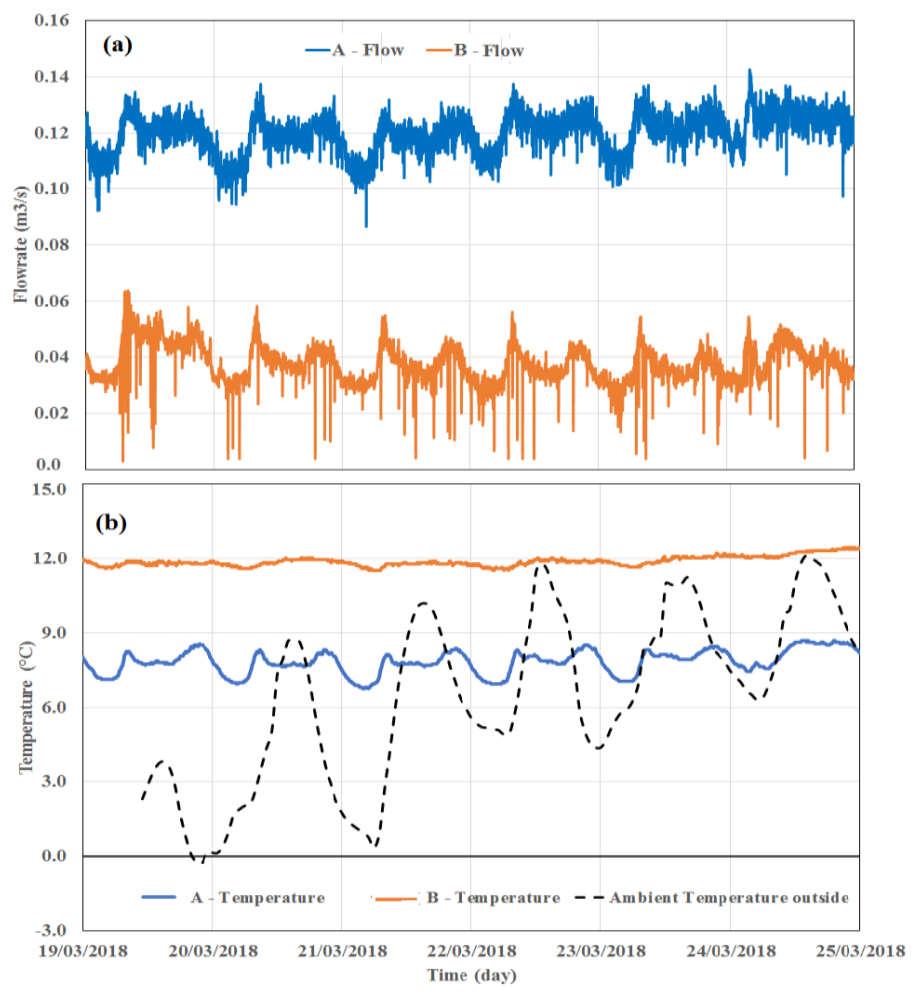

Page $\mid 113$

Fig. 3 Recorded Flows and Temperatures inside sewer at A \& B along with trend of Ambient air temperature outside

The flowrates in Fig 3a clearly show constant daily diurnal or periodic fluctuations (maximum and minimum discharge measured during the day). The minimum discharge occurs during the night (precisely after midnight) as there is no warm discharges in the sewers. The warm discharges at point of measurements starts to increase little before 6:00am, reaching to maximum between 10:00am to noon. After midday, warm discharges at point of measurements drops and stabilizes, a second milder peak (than midday) of warm discharges occurs later in the evening at point of measurements signifying the consumer behavior. The covered period starts from Monday, and the same discharge is observed until Saturday becoming less evident peak on Sunday. It can be observed that both the flowrates changes (maximal and minimal) are more evident than the changes in their respective temperatures (Fig 3b), especially note that the temperature at point A, clearly exhibits two peaks (coinciding with early morning and late evening). The low temperature time series at A suggest that upstream to this point the sewer has sporadic lateral inflows hence the flow has reached steady state temperature. The map suggest this is the case as there are only two connections upstream quite far from point $\mathrm{A}$; a combine sewer and surface-storm flow connection. Considering the lateral inflow at point $\mathrm{B}$, temperature is consistently high and flat throughout with no visible diurnal. In Fig.2, it can be seen that there are close domestic points very near to the connection of major sewer line (point B), the residence time in this connection is relatively short thus the not allowing temperature to achieve steady state as that of in main sewer line (point $\mathrm{A}$ ). This trend is also

Copyright $(2019$ Published by WEENTECH Ltd. The peer-review process is under responsibility of the scientific committee of the 2nd Global Conference on Energy and Sustainable Development, GCESD2018 https://doi.org/10.32438/WPE.58181 
in line with previous work $[9,18]$ that wastewater temperature is highest at/ near the discharge point, hence the potential heat reclamation sites should be in close vicinity of such inflows confirming the technical viability condition also. Additionally, it can be observed in Fig $3 \mathrm{~b}$ that in the monitored time frame, the sewer temperatures (average $7.8^{\circ} \mathrm{C}$ and $11.9^{\circ} \mathrm{C}$ ) at points $\mathrm{A}$ and $\mathrm{B}$ are relatively stable, higher and less effective by average ambient air temperature outside $\left(6.5^{\circ} \mathrm{C}\right)$. All the above measurement trends of flow and temperature; varying from day to day including working and nonworking days, more Page $\mid 114$ pronounced changes in flow than temperature and less responsive to ambient air temperature outside, all corroborates the finding of previous work [9, 16,17] performed between October and March.

\subsection{Modelling Results}

The distinctive features of this site are that it considers a lateral inflow (point B) while the previously conducted TEMPEST studies [10,11] only presents analysis for single sewer line with no lateral inflows. The site also satisfies the typical technical viability criteria (stated in section 2.10; flow requirements $\left(0.162 \mathrm{~m}^{3} / \mathrm{s}\right)$, minimum pipe diameter $(1219 \mathrm{~mm})$, not only closer to consumer proximity $(500 \mathrm{~m})$ but also in close vicinity of major lateral inflow and anticipated heating load (300 to $500 \mathrm{~kW})$. The wastewater inflow temperature to WWTP (also called influent temperature) restriction is not an issue on this site as there is a concentrated urban area (presence of other lateral inflows) downstream of point $\mathrm{C}$ before the sewage reaches to the two pumping stations in south and north west after which it is pumped to the WWTP so there is no serious low temperature implication at the inlet to the pumping stations and WWTP.

The sewer network is modelled in TEMPEST software as a sewer line (Fig. 2) (extended from measuring point $\mathrm{A}$ (node) to point $\mathrm{C}$ (planned energy centre). Where the start node is $\mathrm{A}, \mathrm{A}^{\prime}$ is node with no wastewater inflow but allowing little air exchange, node at $\mathrm{B}$ is a lateral inflow and the end node is $\mathrm{C}$, the point at which temperature is to be determined to calculate the amount of heat recovery potential. This point ' $C$ ' is the anticipated planned energy centre where wastewater recover heat system could be installed to recover heat. The whole length of sewer line is around $500 \mathrm{~m}$. The input data required for setting up the model in TEMPEST is already stated in section 3.2. Initially the steady state average values were used and later measured dynamic time series were inserted for dynamic calculations. For the daily average temperatures at point $\mathrm{A}$ and $\mathrm{B}$ of $7.8^{\circ} \mathrm{C}$ and $11.9^{\circ} \mathrm{C}$, the steady state modelled temperature at point $\mathrm{C}$ by TEMPEST is $8.9^{\circ} \mathrm{C}$. Note that for this particular campaign the downstream temperature at $\mathrm{C}$ was not measured. 


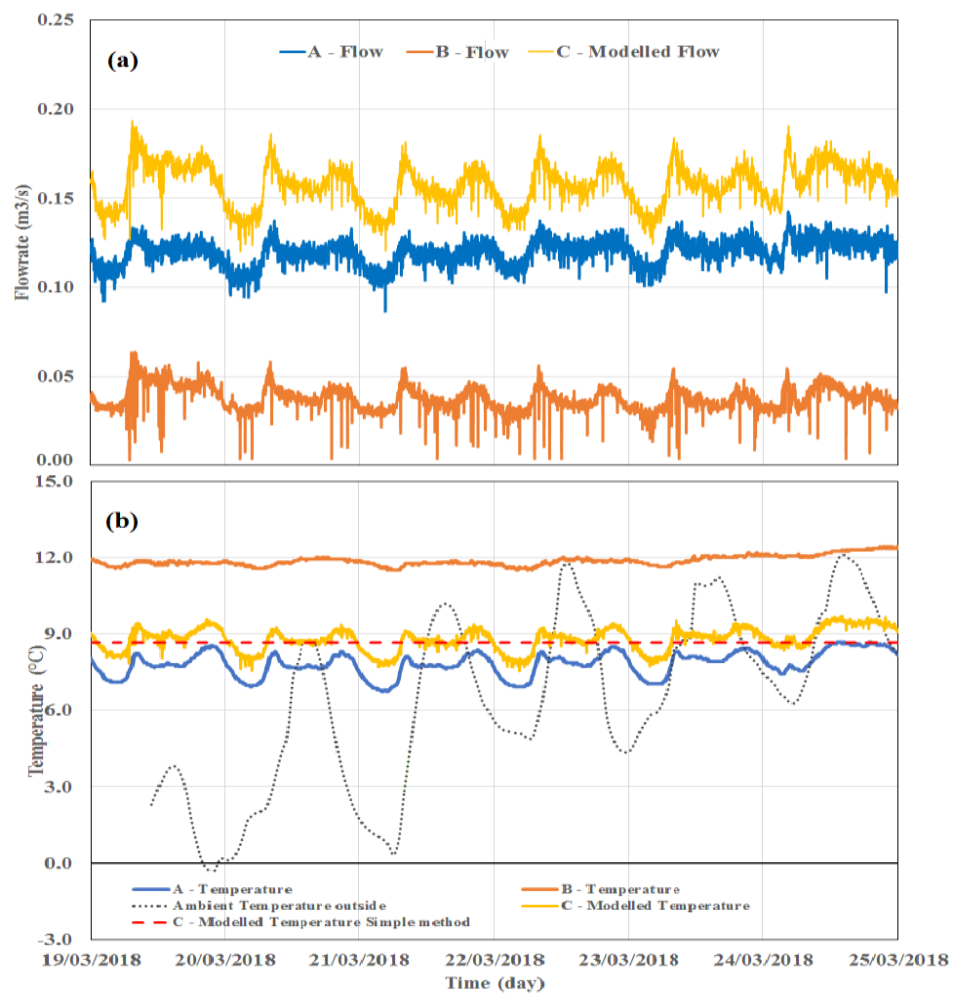

Page $\mid 115$

Fig. 4 Recorded and Modelled Flows and

Temperatures inside sewers network at A \& B

The dynamic modelling results are represented in Fig 4, it shows the measured flows and temperatures along with TEMPEST modelled flow and temperature at point $\mathrm{C}$. As expected (in Fig 4a) TEMPEST predicted discharge at $\mathrm{C}$ is higher than $\mathrm{A}$ and $\mathrm{B}$ because of the mutual contribution of the two flows ( $\mathrm{Q}_{C}$ $\left.=\mathrm{Q}_{\mathrm{A}}+\mathrm{Q}_{\mathrm{B}}\right)$ with the daily diurnal pattern clearly visible. Also in the Fig 4b the TEMPEST modelled temperature at $\mathrm{C}$ is shown. This is the TEMPEST predicted temperature at $\mathrm{C}$ when upstream temperatures are those measured at $\mathrm{A}$ and $\mathrm{B}$. The temperature at $\mathrm{A}$ and of lateral inflow from $\mathrm{B}$ contribute in overall temperature adjustment in the sewer line at point $\mathrm{C}$. Note that the wastewater temperature at downstream point $\mathrm{C}$ is approximately $1^{\circ} \mathrm{C}$ higher than upstream (at point $\mathrm{A}$ ) due to the addition of higher temperature lateral inflow (from point B).

It is emphasised here that the TEMPEST predicted temperature trend corroborates the experimental observation of [19] that lateral inflows at higher temperature than the main sewer flow will positively influence the downstream temperature of the sewer. As no flow and temperature measurement were performed at point $\mathrm{C}$ during measurement period, the predicted temperature cannot be validated at this time. A satisfactory alternative to this limitation is to verify TEMPEST predicted temperature by comparing it with mixture estimation qualitatively. By using this alternate, the temperature is estimated to be $8.7^{\circ} \mathrm{C}$, refer to Fig $4 \mathrm{~b}$ (the constant red dotted line). In comparison to the constant temperature of the alternate, TEMPEST predicted temperature indicate true behaviour similar to that of upstream boundary (point A). Even daily diurnal temperature peaks are also reproduced well by TEMPEST. 


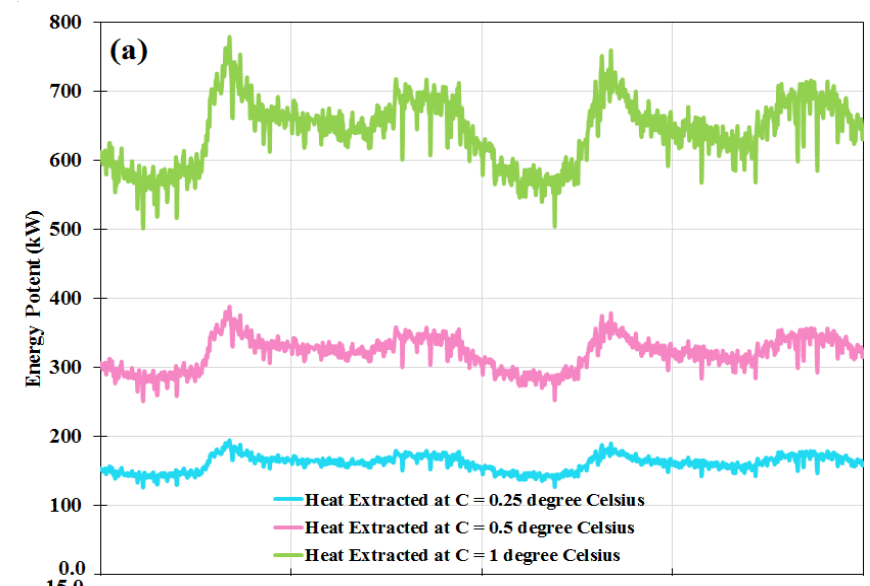

(b)

Page | 116

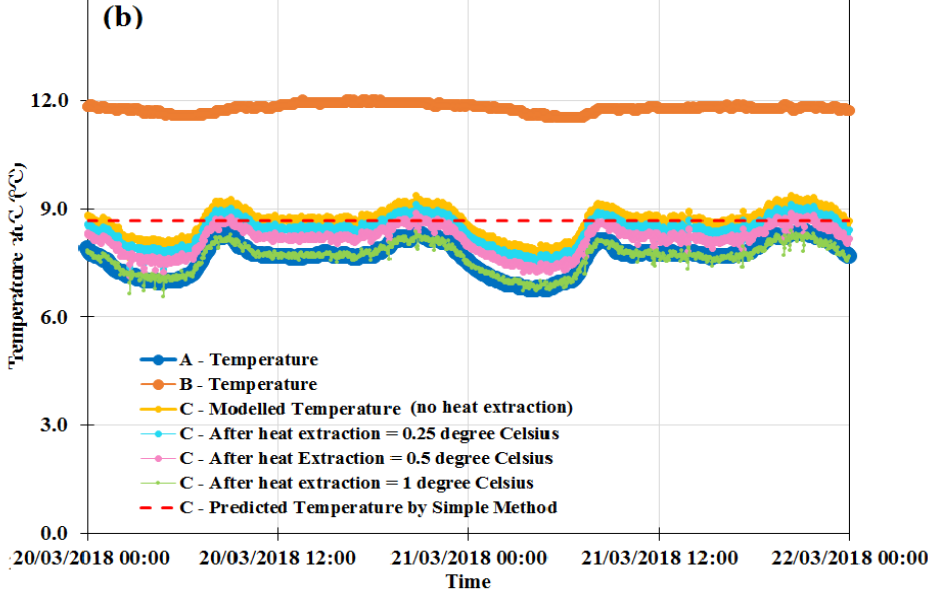

Fig. 5 Heat Recovery Potential from wastewater at the given site in north London

The Fig. 5 shows the heat recovery potentials along with the corresponding temperatures associated after heat recovery. To elucidate the heat recovery potential, above figure only shows the data for two days of March. The temperatures at measuring sites A, B and prediction site $\mathrm{C}$ are also plotted. If the wastewater heat recovery exchanger is placed at the site $\mathrm{C}$ and the drop in sewer wastewater is assume to be $0.25,0.5$ and $1{ }^{\circ} \mathrm{C}$ than the amount of heat recovered in $\mathrm{kW}$ is depicted in Fig 5a obtained by heat balance. As can be seen, higher the wastewater temperature drop, more is the extracted heat averaging from $150 \mathrm{~kW}$ to $350 \mathrm{~kW}$ up till $650 \mathrm{~kW}$. However, refer to Fig $5 \mathrm{~b}$ that wastewater temperature drop of $1^{\circ} \mathrm{C}$ results in temperature as that of measured at $\mathrm{A}$. Thus for this particular case, if heat extraction takes place at site $\mathrm{C}$ than because of the presence of a densely populated area downstream (addition of more lateral inflows to main sewer line) can counteract to keep temperature falling below the legal limit. So it can be concluded that the presence of higher temperature lateral inflows after heat recovery point and before WWTP could prove to be beneficial as they can counter the drop in wastewater temperature and damp out any impact of heat recovery on WWTP inflow.

Note in the figure that heat recovered exhibit diurnal pattern (similar to both flow and temperature maximal and minimal); when sewer inflow is minimum so is the temperature and hence heat recovered, while at peak flow, more is the temperature and heat recovered. This intermittent behavior of recovered heat suggests that in order to make this technology feasible, thermal energy storage should also be considered at design stage so that energy can be recovered when it is available and stored for later use.

Copyright (C) 2019 Published by WEENTECH Ltd. The peer-review process is under responsibility of the scientific committee of the 2nd Global Conference on Energy and Sustainable Development, GCESD2018 https://doi.org/10.32438/WPE.58181 
The Fig. 5 also shows that the alligation alternate fails to capture this diurnal heat recovered and overestimates energy content at $\mathrm{C}$ when sewer inflow is minimum (so is the temperature) and underestimates energy content at $\mathrm{C}$ when sewer inflow is maximum (so is the temperature).

The results from these preliminary measurements are promising. The next step is the detailed measurements for a year period to account for the seasonal variation in the flow and temperature to ensure Page | 117 an efficient heat recovery system design.

\section{Policy implications for UK heat strategy}

The UK heating strategy is fraught with uncertainty. Decarbonising the entire heating sector will require a combination of upgrades to existing electrical systems and the creation of new carbon-free gas (e.g. hydrogen and biogas). All such options carry costly implications for new infrastructure.

Past work has shown considerable potential for low-grade heat recovery (including from wastewater) to offset the need for new low-carbon heating infrastructure. Early results from the HE4T project support that this technical potential is likely to be considerable at the macro level, but subject to considerable spatial and temporal variation at the local level. Fig 3 shows a difference of over $3^{\circ} \mathrm{C}$ in flow temperatures from pipework that is separated by only a small distance (A \& B), as well as very different responses to daily usage peaks, rain events, and external temperatures. This suggests that the static approach of much past research, which focused on engineering calculations and steady state models, will be insufficiently granular to determine the true potential for heat recovery from waste water in a given catchment. The gap between the theoretical potential and what is practically achievable will have costly knock on effects.

The UK will likely be making critical decisions about the future of the gas network in the late 2030s, as well as the nature, cost, and size of the gas network's inevitable replacement. There is therefore an urgent window for delivering waste water heat recovery demonstrations and pilot projects in order to better understand the practical constraints and the likely performance of such systems over time. These demonstrations will also create a vital evidence base upon which to validate more detailed models of wastewater heat recovery systems, particularly the potential to incorporate such models into integrated multi-vector energy systems as part of a cross-sectoral decarbonisation strategy.

\section{Conclusions}

Elsewhere across Europe, wastewater heat recovery is an established technology, however in England this is first pilot trial study. In this paper some preliminary measured data from a London site was analysed, its spatial and temporal distribution was discussed. It was found that for the given set of data, sewer wastewater was less responsive (more stable) to outdoor air temperature making it more suitable heat source for heat pumps than other low grade (air, water and ground) heat sources. In particular, the wastewater flowrate shows more pronounced changes than its temperature. It is observed that the flow and temperature of wastewater in the sewer system shows daily and seasonal variation with higher values in day time than at late night and early morning.

Two-dimensional TEMPEST computer program was used to set up a simple sewer network model consisting of main sewer with lateral inflow and wastewater temperature downstream to the sewer was determined. Different simulated temperature drops from above model indicates that the heat recovery will

Copyright (C) 2019 Published by WEENTECH Ltd. The peer-review process is under responsibility of the scientific committee of the 2nd Global Conference on Energy and Sustainable Development, GCESD2018 https://doi.org/10.32438/WPE.58181 
depend upon upstream flowrate, temperature, allowable temperature drop at the heat recovery site and the efficiency of the wastewater heat recovery system. These heat recovery potential results are encouraging, however further data is needed and therefore it is recommended; to measure the data across the year to capture seasonal effect to optimize the heat recovery, quantitatively verify the model and perform study on the influences of soil temperature, temperature of in-sewer air and the soil thermal conductivity. Further, the impact of surface water and rainfall in combined sewer systems on downstream wastewater Page $\mid 118$ temperature could also not be determined. These are very important and will be investigated in future when more data becomes available. In order to minimise the cost as well as the technical and policy risk, the HE4T project will be validating the modelling approach against measured data for a range of sewer networks over the coming year.

\section{Acknowledgement}

This work is a part of Home Energy for Tomorrow (HE4T) project - a collaborative project between London South Bank University and clean-tech firm (ICAX Ltd.) and is supported by two utility partners Anglian Water and Thames Water. The project is also part funded by the BEIS's Energy Entrepreneur's Fund. The Authors wishes to thank for their support.

\section{ORCID Id of authors}

Farman Ali, Shazia: $\quad 0000-0002-2301-7441$

Gillich, Aaron: $\quad$ 0000-0002-4132-4824

\section{References}

[1] Department of Energy and Climate Change (2013) The future of heating: meeting the challenge.

[2] Ali, F. S. and Gillich, A. (2018) The theoretical versus practical potential of existing and emerging wastewater heat recovery technologies. Energy Systems Conference 2018, QEII Centre, London, UK: 1920 June 2018.

[3] Dunsmore, I. (2016) Heat from wastewater. UK Water Projects.

[4] Fiore, S. and Genon, G. (2014) Heat recovery from municipal wastewater: evaluation and proposals. Environmental Engineering and Management Journal, 13(7) 1595 - 1604.

[5] Berliner, N. E. (2011) Gebäudebezogene Nutzung von Abwasserwärme.

[6] Drenten, S. (2016) Report Summary: wastewater heat recovery UK feasibility. The Cambridge Green Challenge, UK.

[7] Schmidt, F. (2008) Sewage water: interesting heat source for heat pumps and chillers. In proceedings of $9^{\text {th }}$ IEA Heat Pump Conference, Zurich, Switzerland, $2^{\text {nd }}$ May 2008.

[8] Culha, O. H., Gunerhan, E. B. and Hepbasli, A. E. (2015) Heat exchanger applications in wastewater source heat pumps for buildings: a key review. Energy Building, 104, 215 - 232.

[9] Kretschmer, F., Simperler, L. and Thomas, E. (2016) Analysing wastewater temperature development in a sewer system as a basis for the evaluation of wastewater heat recovery potentials. Energy and Buildings, 128, 639 - 648.

[10] Dürrenmatt, D.J and Wanner, O. (2012) User Manual ver. 1.02. Tempest: computer program for the simulation of the wastewater temperature in sewers. Eawag - Swiss Federal Institute of Aquatic Science and Technology.

Copyright $(02019$ Published by WEENTECH Ltd. The peer-review process is under responsibility of the scientific committee of the 2nd Global Conference on Energy and Sustainable Development, GCESD2018 https://doi.org/10.32438/WPE.58181 
[11] Dürrenmatt, D. J. and Wanner, O. (2014) A mathematical model to predict the effect of heat recovery on the wastewater temperature in sewers. Water Research 48, 548 - 558.

[12] Recovering Heat from sewage. Edie.net, (2016) Online: http://wwtonline.co.uk/features/researchnotes-recovering-heat-from-sewage\#.WuxSHIgvzcs (accessed on 23-03-2018)

[13] Investment in waste and wastewater management. Water UK, 2018. Online: https://www.water.org.uk/policy/environment/waste-and-wastewater (accessed on 27-03-2018)

Page | 119 [14] Moran T. Email to author. 09 May 2018.

[15] MacKay, D (2008) Sustainable Energy - without the hot air, UIT Cambridge Ltd.

[16] Abdel-Aal, R., Mohamed, M., Smits, M., De Gussem, K., Tait, S. and Schellart, A. (2014) Modelling the viability of heat recovery from combined sewers. Water Science \& Technology, 70 (2), 297 - 306.

[17] Cipolla, S. S. and Maglionico, M. (2014) Heat recovery from urban wastewater: analysis of the variability of flow rate and temperature. Energy and Buildings 69, 122 - 130.

[18] Wanner, O., Clavadetscher, P., Panagiotidis, V. and Siegrsit, H. (2005) Effect of heat recovery from raw wastewater on nitrification \& nitrogen removal in activated sludge plants. Water Research, 39, 4725 $-4734$.

[19] Schilperoort, R. P. S. and Clemens, F. H. L. R. (2009) Fibre optic distributed temperature sensing in combined sewer systems, Water Science and Technology, 60, 1127 - 1134.

Copyright $(0) 2019$ Published by WEENTECH Ltd. The peer-review process is under responsibility of the scientific committee of the 2nd Global Conference on Energy and Sustainable Development, GCESD2018 https://doi.org/10.32438/WPE.58181 
APPENDIX

Table 1. Wastewater heat recovery examples from around the world

\begin{tabular}{|c|c|c|c|c|c|}
\hline City / Country & $\begin{array}{c}\text { System } \\
\text { mSupplier }\end{array}$ & Arrangement & $\begin{array}{l}\text { HP capacity } \\
\text { / COP }\end{array}$ & Purpose & $\begin{array}{c}\text { Scale / } \\
\text { year }\end{array}$ \\
\hline $\begin{array}{l}\text { Glarus, } \\
\text { Switzerland [7] }\end{array}$ & $\begin{array}{c}\text { Huber } \\
\text { Technology } \\
\text { RoWin }\end{array}$ & $\begin{array}{c}\text { Collector, } \\
\text { Screened } \\
\text { Heat Exchanger }\end{array}$ & $\begin{array}{c}30 \mathrm{~kW} \\
\text { COP } 3.8\end{array}$ & $\begin{array}{l}\text { Heating }+ \\
\text { Hot water }\end{array}$ & $\begin{array}{l}\text { Pilot } \\
(2004)\end{array}$ \\
\hline $\begin{array}{l}\text { Wintower, } \\
\text { Winterthur, } \\
\text { Switzerland [2] }\end{array}$ & $\begin{array}{c}\text { Huber } \\
\text { Technology } \\
\text { RoWin } \\
\end{array}$ & $\begin{array}{c}\text { Collector, } \\
\text { Screened } \\
\text { Heat Exchanger }\end{array}$ & $\begin{array}{c}1.5 \mathrm{MW} \\
\text { COP } 5-6\end{array}$ & $\begin{array}{l}\text { Heating }+ \\
\text { Hot water } \\
+ \text { Cooling } \\
\end{array}$ & $\begin{array}{l}\text { Pilot } \\
(2011)\end{array}$ \\
\hline $\begin{array}{l}\text { Mülheim, } \\
\text { Cologne, } \\
\text { Germany } \\
\text { (CELSIUS } \\
\text { project) [3] }\end{array}$ & $\begin{array}{c}\text { Uhrig } \\
\text { Kanaltechnik } \\
\text { GmbH } \\
\text { Therm-Liner }\end{array}$ & In-Sewer & $150 \mathrm{~kW}$ & Heating & $\begin{array}{l}\text { Pilot } \\
(2014)\end{array}$ \\
\hline $\begin{array}{l}\text { Wahn, Cologne, } \\
\text { Germany } \\
\text { (CELSIUS } \\
\text { project) [3] }\end{array}$ & $\begin{array}{c}\text { Uhrig } \\
\text { Kanaltechnik } \\
\text { GmbH } \\
\text { Therm-Liner }\end{array}$ & In-Sewer & $200 \mathrm{~kW}$ & Heating & $\begin{array}{l}\text { Pilot } \\
\text { (2014) }\end{array}$ \\
\hline $\begin{array}{l}\text { SinTec } \\
\text { Technology Park, } \\
\text { Singen, Germany } \\
{[4]}\end{array}$ & $\begin{array}{c}\text { Uhrig } \\
\text { Kanaltechnik } \\
\text { GmbH } \\
\text { Therm-Liner }\end{array}$ & In-Sewer & $\begin{array}{c}200 \mathrm{~kW}+ \\
243 \mathrm{~kW} \\
\text { COP } 3.5- \\
3.9 \\
\end{array}$ & $\begin{array}{l}\text { Heating / } \\
\text { Cooling }\end{array}$ & $\begin{array}{l}\text { Large } \\
(2004)\end{array}$ \\
\hline $\begin{array}{l}\text { Leverkusen, } \\
\text { Germany [5] }\end{array}$ & $\begin{array}{c}\text { Rabtherm AG } \\
\text { Rabtherm - } \\
\text { Liner } \\
\end{array}$ & In-Sewer & $170 \mathrm{~kW}$ & $\begin{array}{c}\text { Heating }+ \\
\text { Cooling }\end{array}$ & $\begin{array}{l}\text { Pilot } \\
(2003)\end{array}$ \\
\hline $\begin{array}{l}\text { Ryaverket, } \\
\text { Gothenburg, } \\
\text { Sweden [6] }\end{array}$ & $\begin{array}{l}\text { Göteborg } \\
\text { Energi }\end{array}$ & $\begin{array}{l}\text { Effluent at } \\
\text { WWTP }\end{array}$ & $\begin{array}{c}2 \times 50 \mathrm{MW} \\
+2 \times 30 \\
\mathrm{MW} \\
\mathrm{COP} 3 \\
\end{array}$ & $\begin{array}{l}\text { Heating }+ \\
\text { Hot water }\end{array}$ & $\begin{array}{l}\text { Large } \\
(2009)\end{array}$ \\
\hline $\begin{array}{l}\text { Hammarbyverket } \\
\text { in Stockholm, } \\
\text { Sweden [7] }\end{array}$ & Fortum Energi & $\begin{array}{l}\text { Effluent at } \\
\text { WWTP }\end{array}$ & $\begin{array}{l}7 \text { HP with } \\
225 \text { MW } \\
\text { COP } 3.5 \\
\end{array}$ & $\begin{array}{l}\text { Heating }+ \\
\text { Cooling }+ \\
\text { Electricity }\end{array}$ & $\begin{array}{c}\text { Large } \\
(1986,91 \\
\& 97) \\
\end{array}$ \\
\hline Espoo, Finland [8] & Fortum Energi & $\begin{array}{l}\text { Effluent at } \\
\text { WWTP }\end{array}$ & $\begin{array}{c}2 \times 20 \mathrm{MW} \\
+2 \times \\
7.5 \mathrm{MW} \\
\mathrm{COP} 3.0 \\
\end{array}$ & $\begin{array}{l}\text { Heating }+ \\
\text { Hot water }\end{array}$ & $\begin{array}{l}\text { Large } \\
(2014)\end{array}$ \\
\hline $\begin{array}{lr}\text { Katri } & \text { Vala, } \\
\text { Helsinki, Finland } \\
{[8]}\end{array}$ & Friotherm AG & $\begin{array}{l}\text { Effluent at } \\
\text { WWTP }\end{array}$ & $\begin{array}{c}3 \times 30 \mathrm{MW} \\
+2 \times 30 \\
\mathrm{MW} \\
\mathrm{COP} 3.5 \\
\end{array}$ & $\begin{array}{c}\text { Heating }+ \\
\text { Cooling }\end{array}$ & $\begin{array}{l}\text { Large } \\
(2006)\end{array}$ \\
\hline $\begin{array}{l}\text { Sandvika, Oslo, } \\
\text { Norway [1] }\end{array}$ & Friotherm AG & $\begin{array}{c}\text { Screened, } \\
\text { passed to Shell }\end{array}$ & $\begin{array}{c}2 \times 6.5 \mathrm{MW} \\
+2 \times \\
4.5 \mathrm{MW}\end{array}$ & $\begin{array}{l}\text { Heating / } \\
\text { Cooling }\end{array}$ & $\begin{array}{c}\text { Large } \\
(1998 \& \\
08) \\
\end{array}$ \\
\hline
\end{tabular}

Copyright (C) 2019 Published by WEENTECH Ltd. The peer-review process is under responsibility of the scientific committee of the 2nd Global Conference on Energy and Sustainable Development, GCESD2018 https://doi.org/10.32438/WPE.58181 


\begin{tabular}{|c|c|c|c|c|c|}
\hline & & $\begin{array}{l}\text { \& Tube Heat } \\
\text { exchanger }\end{array}$ & COP 3.10 & & \\
\hline $\begin{array}{ll}\text { Sköyen } & \text { Vest, } \\
\text { Oslo, Norway [6] }\end{array}$ & $\begin{array}{c}\text { Hafslund } \\
\text { Fjernvarme AS }\end{array}$ & $\begin{array}{l}\text { Screened, Shell } \\
\text { \& Tube } \\
\text { Exchanger }\end{array}$ & $\begin{array}{l}28 \mathrm{MW}, \\
\text { COP } 2.8\end{array}$ & Heating & $\begin{array}{l}\text { Large } \\
(2005)\end{array}$ \\
\hline $\begin{array}{l}\text { Leuven, Belgium } \\
\text { (INNERS project) } \\
\text { [9] }\end{array}$ & Vlario & $\begin{array}{l}\text { Collector } \\
\text { Plate Heat } \\
\text { Exchanger }\end{array}$ & $\begin{array}{l}250 \mathrm{~kW} \\
\text { COP } 4.5\end{array}$ & $\begin{array}{l}\text { Heating + } \\
\text { Hot water }\end{array}$ & $\begin{array}{l}\text { Small } \\
(2014)\end{array}$ \\
\hline $\begin{array}{l}\text { Budapest Military } \\
\text { Hospital, Hungry } \\
{[10]}\end{array}$ & $\begin{array}{l}\text { Thermowatt } \\
\text { Ltd. }\end{array}$ & $\begin{array}{c}\text { Collector, } \\
\text { Screened } \\
\text { Heat Exchanger }\end{array}$ & $\begin{array}{c}3.8 \mathrm{MW}+ \\
3.4 \mathrm{MW} \\
\text { COP } 6-7\end{array}$ & $\begin{array}{l}\text { Heating / } \\
\text { Cooling }\end{array}$ & $\begin{array}{l}\text { Large } \\
(2014)\end{array}$ \\
\hline $\begin{array}{ll}\text { Budapest } & \text { Sewage } \\
\text { Works, Hungry } \\
{[10]}\end{array}$ & $\begin{array}{l}\text { Thermowatt } \\
\text { Ltd. }\end{array}$ & $\begin{array}{c}\text { Collector, } \\
\text { Screened } \\
\text { Heat Exchanger }\end{array}$ & $\begin{array}{l}1.23 \mathrm{MW}, \\
\text { COP } 4.4\end{array}$ & $\begin{array}{c}\text { Heating / } \\
\text { Cooling }\end{array}$ & $\begin{array}{l}\text { Large } \\
(2012)\end{array}$ \\
\hline $\begin{array}{l}\text { Eco-district } \\
\text { Nanterre, Paris, } \\
\text { France [11] } \\
\end{array}$ & $\begin{array}{c}\text { Suez Ltd. } \\
\text { Degres Bleus }\end{array}$ & In-Sewer & $\begin{array}{c}2 \times 400 \mathrm{~kW}, \\
\text { COP } 2.7\end{array}$ & $\begin{array}{l}\text { Heating + } \\
\text { Hot water }\end{array}$ & $\begin{array}{l}\text { Medium } \\
(2015)\end{array}$ \\
\hline $\begin{array}{lr}\text { Beijing } & \text { Olympic } \\
\text { Village, } & \text { China } \\
{[12]} & \\
\end{array}$ & $\begin{array}{c}\text { Skandinavisk } \\
\text { Termoekonomi } \\
\text { AB }\end{array}$ & $\begin{array}{l}\text { Effluent with } \\
\text { plate Heat } \\
\text { Exchanger }\end{array}$ & \begin{tabular}{|c|}
$4 \times 5.4 \mathrm{MW}$ \\
$+4 \times 5.25$ \\
$\mathrm{MW}, \mathrm{COP}$ \\
3.85 \\
\end{tabular} & $\begin{array}{c}\text { Heating + } \\
\text { Cooling }\end{array}$ & $\begin{array}{l}\text { Large } \\
(2008)\end{array}$ \\
\hline $\begin{array}{l}\text { Whistler Athlete's } \\
\text { Village, BC, BC, } \\
\text { Canada [13] }\end{array}$ & $\begin{array}{l}\text { IWS Sewage } \\
\text { SHARC }\end{array}$ & $\begin{array}{c}\text { Screened \& } \\
\text { Pumped into } \\
\text { evaporator of } \\
\text { HP } \\
\end{array}$ & $3.5 \mathrm{MW}$ & $\begin{array}{c}\text { Heating + } \\
\text { Cooling }\end{array}$ & $\begin{array}{l}\text { Large } \\
(2009)\end{array}$ \\
\hline $\begin{array}{lr}\text { Southeast } & \text { False } \\
\text { Creek, } & \text { BC, } \\
\text { Canada [13] } & \\
\end{array}$ & $\begin{array}{c}\text { IWS Sewage } \\
\text { SHARC }\end{array}$ & $\begin{array}{l}\text { Shell and Tube } \\
\text { Heat Exchanger }\end{array}$ & $2.7 \mathrm{MW}$ & $\begin{array}{l}\text { Heating }+ \\
\text { Hot water }\end{array}$ & $\begin{array}{l}\text { Large } \\
(2010)\end{array}$ \\
\hline
\end{tabular}

Copyright ( $) 2019$ Published by WEENTECH Ltd. The peer-review process is under responsibility of the scientific committee of the 2nd Global Conference on Energy and Sustainable Development, GCESD2018 https://doi.org/10.32438/WPE.58181 